\title{
The role of condensed tannins in the nutritional value of Lotus pedunculatus for sheep
}

\author{
1. Voluntary intake
}

\author{
BY T. N. BARRY AND S. J. DUNCAN \\ Invermay Agricultural Research Centre, Private Bag, Mosgiel, New Zealand
}

(Received 26 April 1983 - Accepted 9 December 1983)

\begin{abstract}
1. Voluntary intake was determined with vegetative Lotus pedunculatus cut and fed fresh to growing sheep of $42-46 \mathrm{~kg}$ live weight. Effects attributable to condensed tannins were assessed by growing the plant under high and low levels of soil fertility, inducing low and high concentrations of tannin (Expt 1), or by binding the tannins through spraying the herbage with polyethylene glycol (molecular weight 3350, PEG; Expt 2). Primary-growth lotus was used in Expt 1 and secondary-growth lotus in Expt 2. Concentrations of total and free condensed tannin were determined in fresh lotus, free tanning being defined as that not bound by mascerates of the plant.

2. In Expt 1 the herbages fed contained respectively 46 and $106 \mathrm{~g}$ total condensed tannin $/ \mathrm{kg}$ dry matter (DM) and 3 and $14 \mathrm{~g}$ free condensed tannin $/ \mathrm{kg} \mathrm{DM}$. Mean metabolizable energy (ME) intakes were 0.89 and $0.77 \mathrm{MJ} / \mathrm{kg}$ live weight ${ }^{0.75}$ per $\mathrm{d}(\boldsymbol{P}<0.05)$ respectively.

3. The lotus used in Expt 2 contained 63 and $5 \mathrm{~g}$ total reactive condensed tannin and free condensed tannin $/ \mathrm{kg}$ DM respectively. After spraying with PEG at $2.4 \mathrm{~g} / \mathrm{g}$ total condensed tannin, these values were reduced to 7 and $0.5 \mathrm{~g} / \mathrm{kg} \mathrm{DM}$ respectively. PEG addition increased apparent digestibility (proportion of each nutrient ingested) of cellulose, hemicellulose and nitrogen by $0.05,0.08$ and 0.26 , and increased ME intake from 0.48 to $0.69 \mathrm{MJ} / \mathrm{kg}$ live weight $\mathrm{t}^{0.75}$ per $\mathrm{d}$.

4. It was concluded that high concentrations of condensed tannins depressed ME intake, due to depressions in both the voluntary intake and digestion of organic matter. The stimulation of hemicellulose and cellulose digestion by PEG addition suggests that the condensed tannin was depressing rumen digestion.

5. It is considered that free tannins are most likely to have been responsible for the depressive effects in the present study. This could be due to their reaction with microbial enzymes in the rumen, the tannin content of the plant exceeding the capacity of the plant protein to bind it, or to reaction with enzymes secreted into the small intestine following the absorption of amino acids. In either instance free tannins could also react with proteins of the gut wall.
\end{abstract}

Reponses in protein deposition in body tissue and in wool to abomasal infusion of casein + methionine in growing lambs fed on fresh ryegrass (Lolium perenne)-based herbage ad lib. have shown that absorption of one or more essential amino acids from the small intestine is below animal requirements (Barry, 1981). A subsequent review (Barry, 1982) concluded that lactating ewes and dairy cows consuming similar fresh pasture ad lib. of high metabolizable energy (ME; 11.3 MJ ME/kg dry matter (DM)) and total nitrogen $(33 \mathrm{~g} / \mathrm{kg} \mathrm{DM})$ content were also likely to be deficient in the absorption of essential amino acids, relative to the requirements for optimum production at the level of voluntary $\mathrm{ME}$ intake achieved. One of the two main predisposing causes of this deficit was identified as the exceptionally high degradation rate of the proteins in fresh forages in the rumen $(0 \cdot 7)$.

The leaves and stems of Lotus pedunculatus contain condensed tannins, which on disintegration of the plant material, such as during chewing, render the forage proteins insoluble (Jones et al. 1973). The presence of condensed tannins therefore makes lotus a non-bloating legume (Ross \& Jones, 1974) and at $15 \mathrm{~g} / \mathrm{kg}$ DM increases duodenal protein flow by reducing plant-protein degradation in the rumen (John \& Lancashire, 1981).

Grasslands 'Maku' lotus is a tetraploid selection of Lotus pedunculatus chosen to suit New Zealand conditions (Armstrong, 1974). It can tolerate lower levels of soil fertility than white clover (Trifolium repens) and is being used at this Centre in Hill Country development programmes on acid soils ( $\mathrm{pH} 4 \cdot 5-4 \cdot 8)$ with very low levels of fertilizer input (Lowther, 1980). 
However, when grown under these conditions 'Maku' lotus contains 80-100 g condensed tannin $/ \mathrm{kg}$ DM compared with $20-40 \mathrm{~g} / \mathrm{kg}$ DM when grown on high fertility lowland soils (Barry \& Forss, 1983), Objectives of the present investigation were to evaluate the effects of condensed tannin content on the voluntary intake of lotus by sheep.

EXPERIMENTAL

Sources of Lotus pedunculatus

Grasslands 'Maku' Lotus pedunculatus (hence referred to as lotus) was grown under high and low levels of soil fertility at Invermay Research Centre and Waiora Hill Country Farm respectively. Single superphosphate ( 0.09 phosphorus, 0.11 sulphur) had been applied to the soils used at Invermay ( $250 \mathrm{~kg} / \mathrm{ha}$ per year) and Waiora ( $100 \mathrm{~kg} / \mathrm{ha}$ per year) for the previous 25 and 2 years respectively. Soil $\mathrm{pH}$ was respectively 5.3 and 4.7 at Invermay and Waiora, and corresponding levels of available $P(\mu \mathrm{g} / \mathrm{g}$ soil) were 18 and 6 respectively, whilst levels of available $S(\mu \mathrm{g} / \mathrm{g}$ soil) were 12 and 4 respectively.

Altitudes of the sites were $50 \mathrm{~m}$ at Invermay and $500 \mathrm{~m}$ at Waiora. The two sites were only $8 \mathrm{~km}$ apart, rainfall patterns were similar, but temperatures were lower at Waiora with the consequence that primary growth of lotus commenced some 5 weeks later at the hill-country site. Both sites were sprayed during winter with a selective weedkiller to control growth of spring grasses (Kerb; Rohm \& Haas, USA) and native tussock was cut and removed from the hill-country site over this period.

\section{Animals}

Castrated Romney male sheep aged 12-18 months were used as experimental animals. Mean weights at the commencement of Expts 1 and 2 were respectively $42 \cdot 1$ (SD $4 \cdot 2$ ) $\mathrm{kg}$ and $46 \cdot 4$ (sD 2.8) kg. Before the start of both experiments the sheep were drenched to remove any internal parasites (Thibenzole; Merck, Sharpe and Dohme (N.Z.) Ltd) and were given orally $2.5 \mathrm{mg}$ selenium as sodium selenate. All sheep were individually fed in pens indoors, with the lotus cut and fed fresh each day. The sheep were weighed after a $24 \mathrm{~h}$ fast at the start and end of Expt 1, and at the start and end of both periods in Expt 2. Mean live weight during each feeding period was used in the calculation of intake per unit metabolic body size (live weight $\mathbf{t}^{0.75}$ ).

\section{Experimental design}

Expt 1. Lotus primary growth was cut from both Invermay and Waiora and fed to eight and four sheep respectively. Lotus grown at Invermay (low-tannin lotus) was fed first, with lotus grown at Waiora (high-tannin lotus), being fed some 5 weeks later, the time difference being the minimum required for primary growth to occur under hill-country conditions. The lotus cut at both sites was at a similar stage of vegetative growth, with no bud or flower development.

Sheep were offered fresh lotus ad lib., with that offered being $1 \cdot 15$ of the previous day's DM consumption. The first $12 \mathrm{~d}$ was used as the pre-feeding period, until voluntary intake stabilized. Voluntary intake was then recorded over the next $10 \mathrm{~d}$. Representative samples of feed offered and residue were taken daily during the period of voluntary intake measurement and were pooled at $-20^{\circ}$; they were then freeze-dried, ground and used for laboratory analyses. Intakes of digestible organic matter were calculated using digestibility coefficients of 0.73 for low-tannin lotus and 0.66 for high-tannin lotus, determined in a quantitative digestion study carried out with the same forages (Barry \& Manley, 1984).

Expt 2. Secondary-growth lotus grown at the hill-country site was fed to six sheep for two periods each of 3 weeks duration. The effect of condensed tannin content on voluntary intake and digestibility was studied using the principle that polyethylene glycol (molecular 
weight 3350; PEG) binds to condensed tannins in preference to protein and will displace protein from pre-formed tannin-protein complexes (Jones \& Mangan, 1977). Barry \& Forss (1983) applied this principle to vegetative lotus in laboratory studies and found that a minimum of $1.8 \mathrm{~g} \mathrm{PEG} / \mathrm{g}$ condensed tannin was required to reverse all the effects of condensed tannins. Consequently, two treatments were applied to the lotus used in the present animal experiment; half the forage cut each day was sprayed with a solution of PEG $(0.30 \mathrm{~g} / \mathrm{g})$ at a rate of $2.4 \mathrm{~g} \mathrm{PEG} / \mathrm{g}$ total condensed tannin, whilst the remainder was sprayed with an equivalent volume of water. Control and PEG-treated lotus were fed to each of three sheep for 22-d periods, with the diets changed-over between periods. All sheep were fed on low-tannin lotus for $7 \mathrm{~d}$ between the two periods, to eliminate carry-over effects. Voluntary intake was determined as described in Expt 1, with faeces also being collected over the last $10 \mathrm{~d}$ of each feeding period.

\section{Laboratory methods}

Total condensed tannin content of fresh lotus was determined by the method of Broadhurst \& Jones (1978). Tannin detected in PEG-treated lotus was defined as total reactive condensed tannin. Free condensed tannin was measured as that present in the supernatant fraction after fresh lotus was ground with sand in phosphate buffer $\left(\mathrm{pH} \mathrm{7.0)}\right.$ at $4^{\circ}$, followed by centrifugation at $20000 \mathrm{~g}$ for $30 \mathrm{~min}$ (Barry \& Forss, 1983). The latter method measures the quantity of tannin which was not bound by finely-mascerated lotus tissue (free tannin).

Carbohydrates (CHO) were determined by the fractionation procedure of Bailey (1967), total $\mathrm{N}$ by the Kjeldahl method, plant mineral concentration as described by Barry (1980) and soil chemistry as described by Barry \& Forss (1983).

\section{Statistical methods and calculation of results}

Analysis of variance procedures were used. In the analyses of Expt 2, animal groups formed the first level in the analyses of variance and PEG supplementation formed the second level. The design thus rendered maximum precision for assessment of PEG effects and the detection of any PEG $v$. animal-group interactions. None of the latter were close to attaining significance $(P>0.05)$.

$\mathrm{ME}$ intake was calculated assuming 16.3 MJ ME $/ \mathrm{kg}$ digestible organic matter (DOM) intake (Ulyatt et al. 1980). In Expt 2, the digestibilities of organic matter (OM) and energy were calculated on the assumption that all PEG consumed was quantitatively excreted in the faeces, with the faecal outputs of $\mathrm{OM}$ and energy being corrected on this basis.

\section{RESULTS}

Expt 1

Lotus grown under low soil fertility conditions contained more than twice as much total condensed tannin as lotus grown under high soil fertility conditions (Table 1). Free condensed tannin was easily detectable in both herbages, but was present in approximately five times greater concentration in high-tannin lotus than in low-tannin lotus. Total $\mathbf{N}$ content was less and lignin concentration slightly greater in high-tannin lotus compared with low-tannin lotus, but the two forages were remarkably similar in CHO composition.

Voluntary intake was less for high-tannin lotus than for low-tannin lotus (Table 2) with the difference for DOM and ME intake attaining significance $(P<0.05)$.

\section{Expt 2}

Spraying with PEG reduced the total reactive condensed tannin concentration in lotus from 63 to $7 \mathrm{~g} / \mathrm{kg}$ DM (Table 3) and reduced the free tannin concentration to negligible proportions. Apparent digestion (proportion of each nutrient ingested) of lotus OM and 
Table 1. Chemical composition $(\mathrm{g} / \mathrm{kg}$ dry matter $(D M))$ of primary-growth Lotus pedunculatus with low and high contents of condensed tannin, induced by growing under conditions of high and low levels of soil-available nutrients

\begin{tabular}{|c|c|c|}
\hline & $\begin{array}{c}\text { Low-tannin } \\
\text { lotus }\end{array}$ & $\begin{array}{l}\text { High-tannin } \\
\text { lotus }\end{array}$ \\
\hline Total condensed tannin & $45 \cdot 6$ & $105 \cdot 9$ \\
\hline Free condensed tannin & $3 \cdot 0$ & $14 \cdot 2$ \\
\hline & $(0.07)^{*}$ & $(0 \cdot 13)^{*}$ \\
\hline Organic matter & 898.9 & $935 \cdot 7$ \\
\hline Heat of combustion (MJ/kg DM) & $19 \cdot 11$ & $19 \cdot 83$ \\
\hline Total nitrogen & $41 \cdot 3$ & $31 \cdot 6$ \\
\hline Soluble carbohydrates & $114 \cdot 5$ & $128 \cdot 7$ \\
\hline Total pectins & 68.4 & $55 \cdot 1$ \\
\hline Hemicellulose & $85 \cdot 1$ & $88 \cdot 5$ \\
\hline Cellulose & 147.9 & $135 \cdot 2$ \\
\hline Lignin & $132 \cdot 0$ & $152 \cdot 2$ \\
\hline Total phosphorus & $3 \cdot 8$ & $2 \cdot 3$ \\
\hline Total sulphur & $3 \cdot 2$ & $2 \cdot 4$ \\
\hline Sulphate-S & $1 \cdot 2$ & 0.5 \\
\hline
\end{tabular}

* Ratio, free: total condensed tannin.

Table 2. Voluntary intakes ( $\mathrm{g} / \mathrm{kg}$ live weight $\left.{ }^{0.75} \mathrm{per} d\right)$ of primary-growth Lotus pedunculatus with low and high contents of condensed tannin, induced by growing under conditions of high and low levels of soil-available nutrients

(Mean values with their standard errors of the difference for eight and four animals fed on low-tannin lotus and high-tannin lotus respectively)

\begin{tabular}{lccc}
\hline \hline & $\begin{array}{c}\text { Low-tannin } \\
\text { lotus }\end{array}$ & $\begin{array}{c}\text { High-tannin } \\
\text { lotus }\end{array}$ & SED \\
\hline Dry matter & 83.3 & 76.8 & $3 \cdot 71$ \\
Organic matter & 75.0 & $71 \cdot 8$ & 3.41 \\
Digestible organic matter & 54.5 & 47.3 & 2.41 \\
Metabolizable energy* & 0.89 & 0.77 & 0.038 \\
\hline
\end{tabular}

* $\mathrm{MJ} / \mathrm{kg}$ live weight ${ }^{0.75}$ per $\mathrm{d}$.

Table 3. Chemical composition ( $\mathrm{g} / \mathrm{kg}$ dry matter $(D M)$ ) of secondary-growth Lotus pedunculatus before and after spraying with polyethylene glycol (PEG*)

\begin{tabular}{lcc}
\hline & Before spraying & After spraying \\
\hline Total reactive condensed tannin & 62.9 & 6.8 \\
Free condensed tannin & 5.4 & 0.5 \\
& $(0.09) \dagger$ & $(0.07) \dagger$ \\
Organic matter & 925.4 & \\
Total nitrogen & 25.2 & \\
Hemicellulose & 118.6 & \\
Cellulose & 188.3 & \\
Lignin & 182.1 & \\
Total phosphorus & 1.9 \\
Total sulphur & 2.0 \\
Sulphate-S & 0.3 \\
\hline \hline
\end{tabular}

* Molecular weight 3350 , applied at $2.4 \mathrm{~g}$ PEG $/ \mathrm{g}$ total condensed tannin.

$\dagger$ Ratio, free: total condensed tannin. 
Table 4. Effect of spraying with polyethylene glycol (molecular weight 3350;PEG) solution ( $2.4 \mathrm{~g} / \mathrm{g}$ condensed tannin) on the apparent digestibility (proportion of each nutrient ingested) of Lotus pedunculatus grown under conditions of low soil fertility

(Mean values with their standard error of the difference for six animals per treatment group)

\begin{tabular}{|c|c|c|c|}
\hline & \multicolumn{2}{|c|}{ Apparent digestibility } & \multirow[b]{2}{*}{ SED } \\
\hline & $\begin{array}{c}\text { Without } \\
\text { PEG }\end{array}$ & $\begin{array}{l}\text { With } \\
\text { PEG }\end{array}$ & \\
\hline Organic matter & 0.547 & 0.627 & 0.0069 \\
\hline Gross energy & 0.514 & 0.597 & 0.0087 \\
\hline Cellulose & 0.527 & 0.579 & 0.0185 \\
\hline Hemicellulose & 0.506 & 0.589 & 0.0142 \\
\hline Total nitrogen & 0.479 & 0.742 & 0.0182 \\
\hline Lignin & 0.015 & 0.035 & 0.0147 \\
\hline
\end{tabular}

Table 5. Voluntary intakes $\left(\mathrm{g} / \mathrm{kg}\right.$ live weight ${ }^{0.75}$ per $d$ ) in sheep fed on Lotus pedunculatus, with and without spraying with polyethylene glycol (molecular weight $3350 ; P E G$ ) at $2.4 \mathrm{~g} / \mathrm{g}$ condensed tannin

(Mean values with their standard errors of the difference for six animals per treatment group)

\begin{tabular}{lccc}
\hline & \multicolumn{2}{c}{ Voluntary intake } & \\
\cline { 2 - 3 } & Without & With & \\
& PEG & PEG & SED \\
\hline Organic matter & 53.5 & 67.7 & 7.21 \\
Digestible organic matter & 29.2 & $42 \cdot 3$ & 3.99 \\
Metabolizable energy* & 0.48 & 0.69 & 0.069 \\
Digestible total nitrogen & 0.75 & 1.44 & 0.113 \\
Digestible fibre $\dagger$ & 8.8 & 13.0 & 1.70 \\
\hline
\end{tabular}

${ }^{*} \mathrm{MJ} / \mathrm{kg}$ live weight ${ }^{0.75}$ per $\mathrm{d}$.

† Digestible cellulose + digestible hemicellulose + digestible lignin.

energy was increased 0.08 by PEG addition $(P<0.001$; Table 4$)$. PEG addition likewise increased the apparent digestion of cellulose by $0.05(P<0.05)$, hemicellulose by 0.08 $(P<0.01)$ and total $\mathrm{N}$ by $0.26(P<0.001)$. Lignin was virtually indigestible and was little increased by PEG addition $(P>0.05)$.

Lotus voluntary intake was increased by PEG addition (Table 5) with the increases attaining significance for DOM, ME, digestible fibre $(P<0.05)$ and for digestible total $\mathrm{N}$ $(P<0.01)$. Mean PEG intake was $190 \mathrm{~g} / \mathrm{d}$, corresponding to $145 \mathrm{~g} / \mathrm{kg}$ lotus DM intake or $4.0 \mathrm{~g} / \mathrm{kg}$ live weight per $\mathrm{d}$.

\section{DISCUSSION}

The comparison of high-tannin lotus with low-tannin lotus in Expt 1 is confounded with time, but this was the only way that primary growths could be compared. Voluntary ME intake of high-tannin lotus was 0.87 that of low-tannin lotus, and could conceivably be partly due to other factors besides the difference in condensed-tannin content. However, the design of Expt 2 answers this criticism, with PEG addition specifically removing effects attributable to condensed tannins and ME intake of PEG-treated lotus being 1.44 times that of control lotus. Expt 2 can be criticized in that faecal OM output had to be corrected 
for PEG excretion in order to calculate OM digestibility and ME intake. However, this is not necessary when calculating the digestion and voluntary intake of structural $\mathrm{CHO}$ and $\mathrm{N}$; the similarity of these results to those for OM and ME suggests that correcting faecal OM output for PEG excretion was valid. From Expt 2 it seems that moderate concentrations of condensed tannins in lotus depress $\mathrm{ME}$ intake through depressing both the voluntary intake and digestion of OM, with hemicellulose being the structural $\mathrm{CHO}$ most affected. Total condensed tannin content in Expt $2(63 \mathrm{~g} / \mathrm{kg} \mathrm{DM})$ was only slightly greater than that of the low-tannin lotus used in Expt $1(46 \mathrm{~g} / \mathrm{kg} \mathrm{DM})$; hence it is quite likely that intake of the latter was depressed to some extent by condensed tannins.

In quantitative digestion work involving the forages fed in Expt 1, total $\mathrm{N}$ gain across the rumen was much greater for high-tannin lotus than for low-tannin lotus $(10 \cdot 5 v .1 .9 \mathrm{~g} / \mathrm{d})$, whilst post-ruminal digestion of non-ammonia-N (NAN) was similar for both forages $(0.67$ v. 0.71) of NAN arriving at the duodenum (Barry \& Manley, 1984). These effects of high condensed tannin concentrations on protein digestion are very beneficial and reinforce the conclusions of Barry \& Forss (1983) that high levels of lotus tannin are necessary to prevent deamination of plant protein by mixed rumen micro-organisms. Such high tannin levels could, however, depress intake by two means. First, they will cause increased intakes of free tannin into the rumen, as lotus free tannin content is strongly and positively correlated with the total condensed tannin content (Barry \& Forss, 1983). Second, the almost complete release of NAN in the intestines of sheep fed on high-tannin lotus means that large quantities of free tannin will be released into the small intestine during protein digestion. Free condensed tannins are highly reactive, have an affinity for forming hydrogen-bonded complexes with proteins, and are known to react with and precipitate microbial and digestive enzymes (McLeod, 1974). Free tannin in the rumen was probably responsible for the large depression of hemicellulose digestion in the absence of PEG observed in Expt 2; its presence in the rumen and intestine could also be be a cause of depressed voluntary intake.

In New Zealand studies comparing relative growth rates of young sheep grazing pure forage species (John \& Lancashire, 1981), perennial ryegrass rated lowest (1.0), white clover rated highest (1.9) and lotus rated second highest (1.7), slightly ahead of lucerne (Medicago sativa) and red clover $(1 \cdot 5)$. In these trials the plants were grown on a high-fertility soil at Palmerston North in the North Island, under somewhat higher environmental temperatures and rainfall than those used to grow the lotus used in the present investigation. Lotus grown under these conditions at Palmerston North contained $20 \mathrm{~g}$ total condensed tannins $/ \mathrm{kg} \mathrm{DM}$ (John \& Lancashire, 1981), corresponding to the level at which Barry \& Forss (1983) predicted the free-tannin content to be zero. In a comparable grazing trial conducted at this Centre with growing sheep grazing primary-growth lotus containing 80 and $9 \mathrm{~g}$ total and free condensed tannin $/ \mathrm{kg} \mathrm{DM}$ respectively, growth rates of animals drenched daily with $100 \mathrm{~g}$ PEG $(166 \mathrm{~g} / \mathrm{d})$ were greater $(P<0.05)$ than those of control lambs $(125 \mathrm{~g} / \mathrm{d})$ drenched daily with an equivalent volume of water (T. N. Barry, unpublished results). Comparable sheep grazing areas oversown with a mixture of white and red clover, containing only traces of condensed tannins, showed no response to PEG drenching. These trials confirm that high concentrations of condensed tannin depress body growth in young sheep grazing Lotus pedunculatus, and show that the stimulating effects of PEG administration are specific to tannin-containing legumes.

Clearly, further work is required to define the optimum concentration of condensed tannin in vegetative tissue of Lotus pedunculatus in terms of reducing protein degradation in the rumen, increasing post-ruminal absorption of NAN and preventing depressions in ME intake. From the present investigation, and those of Barry \& Forss (1983) and Barry \& Manley (1984), it is conceivable that optimum concentration for protein digestion may 
cause depressions in ME intake and, likewise, optimum concentration to ensure maximum ME intake may confer only small benefits in improving the efficiency of protein digestion.

Finally, the conclusions reached in these investigations with fresh Lotus pedunculatus do not necessarily apply to diets of fresh sainfoin (Onobrychis viciifolia Scop.), the other tannin-containing temperate legume. Molecular weights of the condensed tannins are 7700 for Lotus pedunculatus (Barry \& Forss, 1983) and 22000 for sainfoin (Jones \& Mangan 1977) and, whilst sainfoin contains $60 \mathrm{~g}$ total condensed tannin/ $\mathrm{kg} \mathrm{DM}$ (John \& Lancashire 1981), mascerates of the plant contain no soluble protein and no free tannin (J. L. Mangan, personal communication).

The authors wish to acknowledge technical assistance by B. A. Veenvliet and A. W. Williams, laboratory analyses by T. R. Manley and Mrs J. Crosbie, and statistical advice by Dr S. F. Crosbie.

\section{REFERENCES}

Armstrong, C. S. (1974). New Zealand Journal of Experimental Agriculture 2, 333-336.

Bailey, R. W. (1967). New Zealand Journal of Agricultural Research 10, 15-32.

Barry, T. N. (1980). New Zealand Journal of Agricultural Research 23, 427-431.

Barry, T. N. (1981). British Journal of Nutrition 46, 521-532.

Barry, T. N. (1982). Proceedings of the Nutrition Society of New Zealand 7, 66-76.

Barry, T. N. \& Forss, D. A. (1983). Journal of the Science of Food and Agriculture 34, 1047-1056.

Barry, T. N. \& Manley, T. R. (1984). British Journal of Nutrition 51, 493-504.

Broadhurst, R. W. \& Jones, W. T. (1978). Journal of the Science of Food and Agriculture 29, $788-794$.

John, W. \& Lancashire, J. A. (1981). Proceedings of the New Zealand Grassland Association 42, $152-159$.

Jones, W. T., Anderson, L. B. \& Ross, M. D. (1973). New Zealand Journal of Agricultural Research 16, $441-446$.

Jones, W. T. \& Mangan, J. L. (1977). Journal of the Science of Food and Agriculture 28, 126-136.

Lowther, W. L. (1980). New Zealand Journal of Experimental Agriculture 8, 131-138.

McLeod, N. M. (1974). Nutrition Abstracts and Reviews 44, 803-815.

Ross, M. D. \& Jones, W. T. (1974). New Zealand Journal of Agricultural Research 17, 191-195.

Ulyatt, M. J., Fennessy, P. F., Rattray, P. V. \& Jagusch, K. T. (1980). In Supplementary Feeding, Occasional Publication of New Zealand Society of Animal Production, no. 7, pp. 157-184. [K. R. Drew and P. F. Fennessy, editors]. Mosgiel: New Zealand Society of Animal Production. 